$\frac{12}{6}-15-95 y 5(1)$

UCRL-ID-18991-93

\title{
CALIFORNIA ENERGY FLOW IN 1993
}

\author{
1. Y. Borg \\ C. K. Briggs
}

April 1, 1995

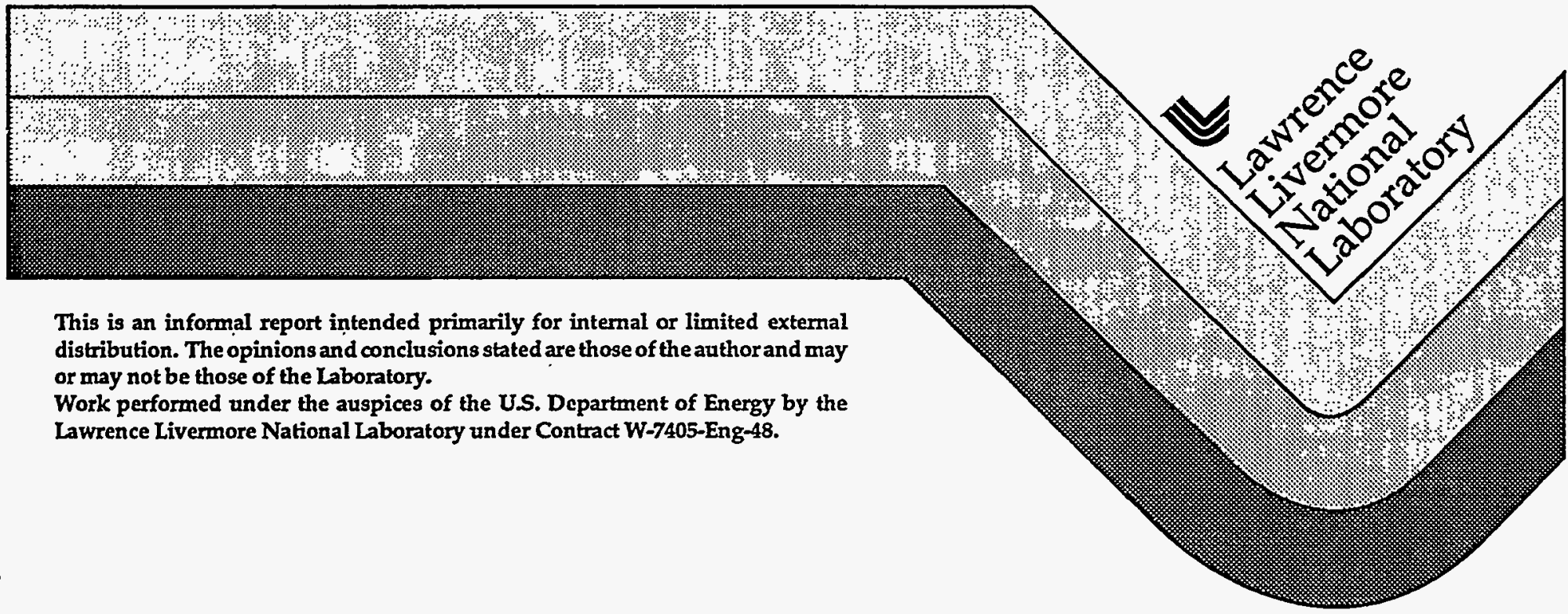




\section{DISCLAMER}

This document was prepared as an account of work sponsored by an agency of the United States Government. Neither the United States Government nor the University of California nor any of their employees, makes any warranty, express or implied, or assumes any legal liability or responsibility for the accuracy, completeness, or usefulness of any information, apparatus, product, or process disclosed, or represents that its use would not infringe privately owned rights. Reference herein to any specific commercial product, process, or service by trade name, trademark, manufacturer, or otherwise, does not necessarily constitute or imply its endorsement, recommendation, or favoring by the United States Government or the University of California. The views and opinions of authors expressed herein do not necessarily state or reflect those of the United States Government or the University of California, and shall not be used for advertising or product endorsement purposes.

This report has been reproduced directly from the best available copy.

Available to DOE and DOE contractors from the Office of Scientific and Technical Information

P.O. Box 62, Oak Ridge, TN 37831

Prices available from (615) 576-8401, FTS 626-8401

Available to the public from the National Technical Information Service

U.S. Department of Commerce

5285 Port Royal Rd.,

Springfield, VA 22161 


\section{DISCLAIMER}

Portions of this document may be illegible in electronic image products. Images are produced from the best available original document. 


\author{
I. Y. Borg \\ C. K. Briggs
}

April 1, 1995 
CONTENTS

Page

$\begin{array}{lc}\text { ABSTRACT } & 1\end{array}$

INTRODUCTION

- CALIFORNIA ENERGY FLOW DIAGRAMS 2

CALIFORNIA'S ENERGY FLOW IN 1993 COMPARED TO 1992

The economy

Energy consumption

TRANSPORTATION FUELS

Consumption

Vehicle emission standards

OIL AND GAS PRODUCTION

13

Oil production

Natural gas production

OIL AND NATURAL GAS SUPPLY

Oil supply

Natural gas supply

ELECTRICPOWER 16

$\begin{array}{ll}\text { Source of supply } & 16\end{array}$

Nuclear power

Hydropower

Nonutility generation

Alternate sources of electricity

Geothermal power

Solar electricity

Windpower

APPENDIX A Energy balance for 1993

APPENDIX B Data Sources for California Energy Supply - 1993

APPENDIX C Data Sources for California End- Uses - $1993 \quad 24$

APPENDTX D Conversion Units and Assumed Conversion Efficiencies 25

REFERENCES $\quad 26$ 


\section{ABSTRACT}

Energy consumption in the state of California decreased about 3\% in 1993 reflecting continuation of the recession that was manifest in a moribund construction industry and a high state unemployment that ran counter to national recovery trends. Residential/commercial use decreased slightly reflecting a mild winter in the populous southern portion of the state, a decrease that was offset to some extent by an increase in the state population. Industrial consumption of purchased energy declined substantially as did production of self-generated electricity for in-house use. Consumption in the transportation sector decreased slightly. The amount of power transmitted by the utilities was at 1992 levels; however a smaller proportion was produced by the utilities themselves. Generation of electricity by nonutilities, primarily cogenerators and small power producers, was the largest of any state in the U.S. The growth in the number of private power producers combined with increased amounts of electricity sold to the public utilities set the stage for the sweeping proposals before the California Public Utility Commission to permit direct sales from the nonutilities to retail customers.

California production of both oil and natural gas declined; however, to meet demand only the imports of natural gas increased. A break in the decade-long drought during the 1992-1993 season resulted in a substantial increase in the amount of hydroelectricity generated during the year. Geothermal energy's contribution increased substantially because of the development of new resources by small power producers. Decline in steam production continued at The Geysers, the state's largest field, principally owned and managed by a public utility. Increases in windpower constituted $1-1 / 2 \%$ of the total electric supply- up slightly from 1992 . Several solar photo voltaic demonstration plants were in operation, but their contribution remained small. 


\section{INTRODUCTION}

For the past seventeen years energy flow diagrams for the State of California have been prepared from available data by members of the Lawrence Livermore National Laboratory. ${ }^{1}$ They have proven to be useful tools in graphically expressing energy supply and use in the State as well as illustrating the difference between particular years and between the State and the U.S. as a whole.

As far as is possible, similar data sources have been used to prepare the diagrams from year to year and the same assumptions ${ }^{1 \mathrm{a}-1 \mathrm{e}}$ concerning conversion efficiencies have been made in order to minimize inconsistencies in the data and analyses. A reexamination of transportation efficiencies, ${ }^{2}$ especially those associated with the highway vehicles, has led to the downward revision of the percent used in the figures presented here for 1992 and 1993. Sources of data used in this report are given in Appendix B and C. We continue to see differences in specific data for a given year reported by our principal sources - U.S. Department of Energy, Energy Information Administration and the California Energy Commission. In particular, reported data on supply and usage in the industrial and commercial/residential end-use categories have varied between reporting agencies. However revisions in the data subsequently published by both principal sources have brought them into closer agreement and are reflected in revised energy flow diagrams, one of which is included here.

\section{CALIFORNIA ENERGY FLOW DIAGRAMS}

California energy flow diagrams for 1993 and 1992 are shown in Figs. 1 and 2, respectively. For comparison the U.S. energy flow for 1993 is shown in Fig. $3 .{ }^{2}$ Energy sources are shown on the left and energy consumption is shown on the right. The energy balance between the two is given in Appendix A. Also shown on the right of Figs. 1, 2, \& 3 is the division between "useful" and "rejected" energy based on estimates of conversion efficiencies in the various end-use sectors. "Rejected energy" consists primarily of heat losses. Conversion and plant losses at electric utility generation stations burning fossil fuels are a matter of record, but inputs to total transmitted electricity such as nuclear, geothermal power, etc. are associated with estimated efficiencies of the conversion process to electricity. These estimates vary from $90 \%$ in the case of hydroelectric power to $18 \%$ for geothermal energy. This year we have revised our estimate of efficiency for the transportation sector from 25 to $20 \%$ after a review of the subject. ${ }^{2}$ The estimates of conversion efficiencies are given in Appendix D, and their rationale can be found in Refs. $1 \mathrm{~b}, 1 \mathrm{c}$ and 2. 


\section{CALIFORNIA ENERGY FLOW -1993 TOTAL CONSUMPTION $7000 \times 10^{12} \mathrm{Btu}$}

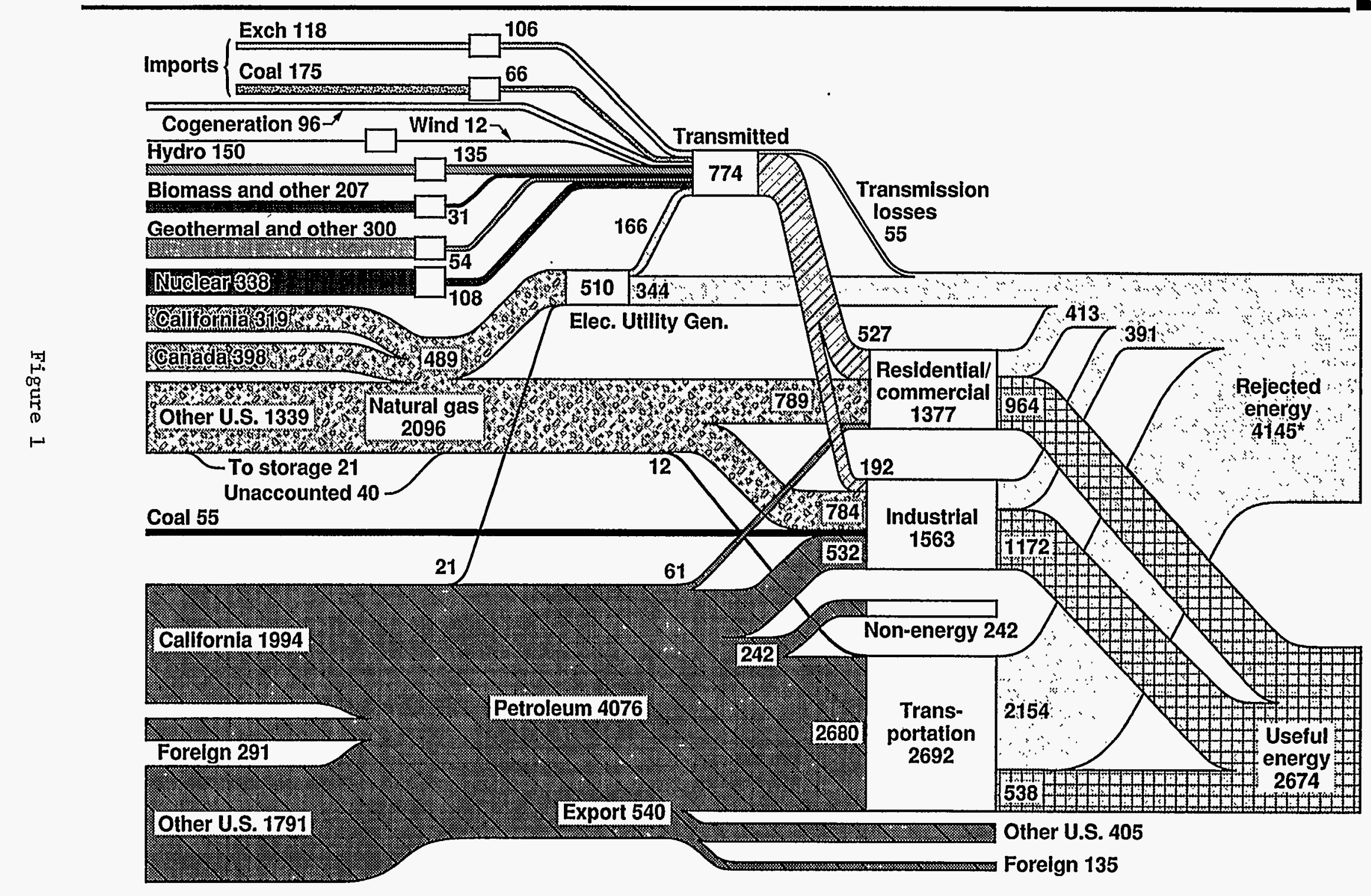

1. Borg/C. Brlggs

CAL ENERGY FLOW 93 prellminary 2.95

* Includes rejected energy for hydro, coal, geothermal, and nuclear conversions 


\section{CALIFORNIA ENERGY FLOW -1992 TOTAL CONSUMPTION $7200 \times 10^{12} \mathrm{Btu}$}

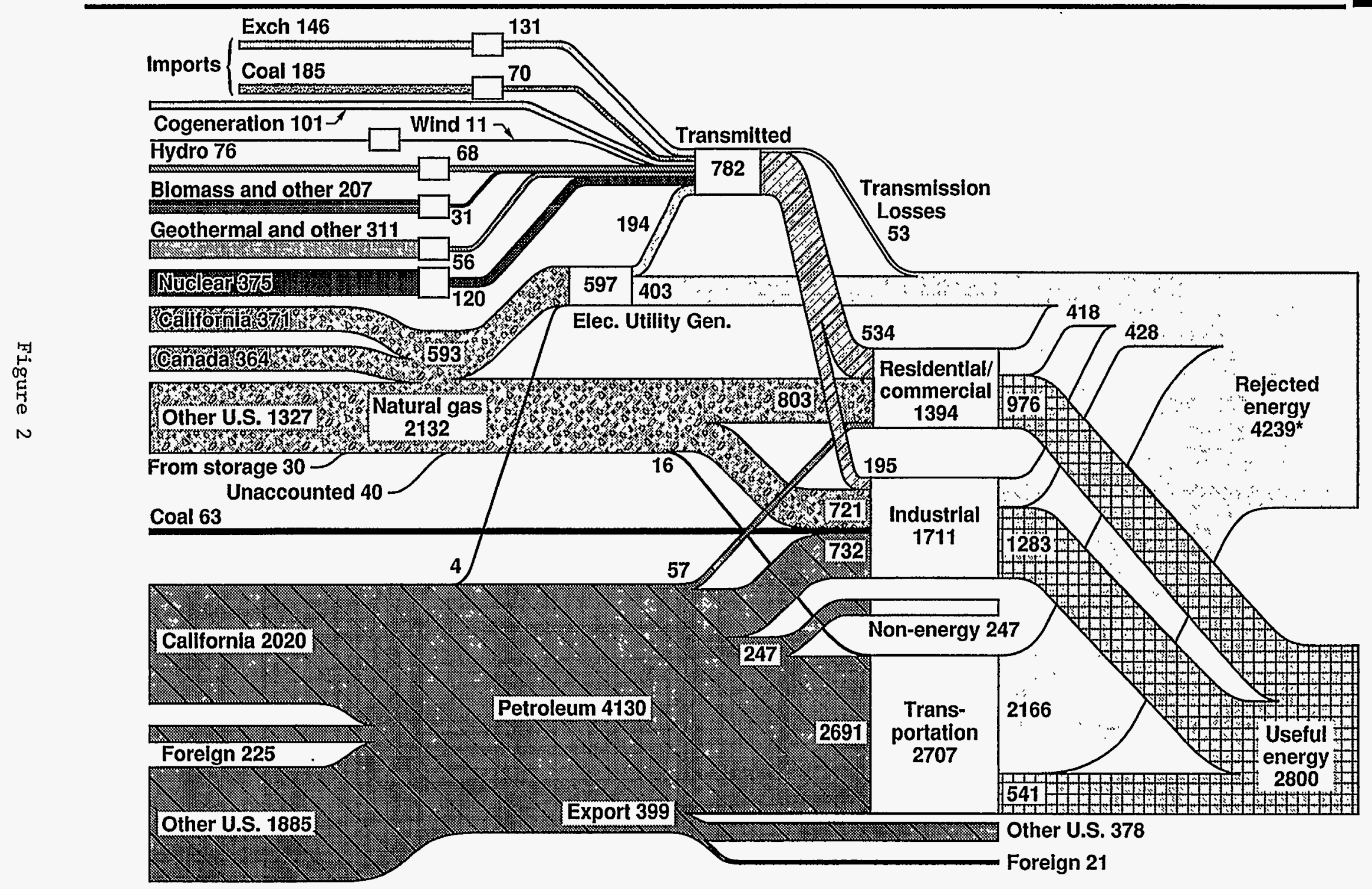




\section{U.S. Energy Flow - 1993 \\ Net Primary Resource Consumption 84 Quads}

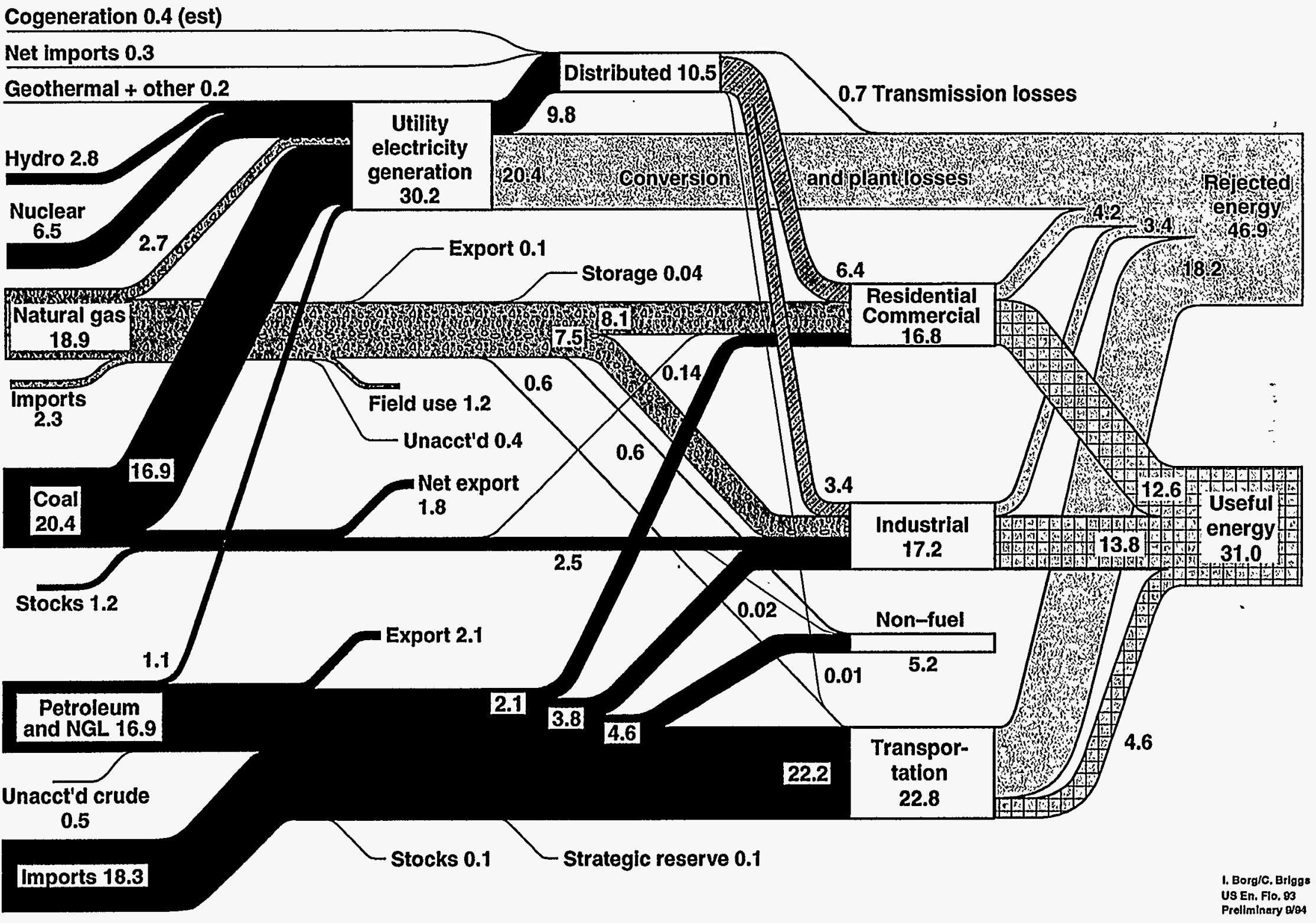

Other: wood, waste, photovoltalc, solar 
The box separating the energy source from the final electrical output represents the conversion process. In all cases the quantities associated with the energy source are calculated based on the assumed conversion efficiencies. While it is desirable to minimize the number of assumptions in preparing an energy flow diagram, it is also desirable to express as closely as possible the energy content of the sources used during the year. In this way it is possible to see at a glance which energy sectors are associated with the greatest conversion losses and thus the largest targets for potential technological improvements in conversion efficiencies.

Power from cogenerators that is sold to utilities is shown in the figures as inputs to total transmitted electricity and appear without a box (representing the conversion process) that ordinarily would appear between the energy content of the fuel and the final product. In this instance, electric conversion losses are included in "rejected energy" from the industrial sector. Not shown in the flow diagrams is the amount of electricity used "in house" by the cogenerators and self generators, but an estimate is given in the section on Nonutility generation. Thus the amount of electricity consumed by the industrial sector, $192 \times 10^{12} \mathrm{Btu}$ in Fig. 1, represents purchases from the utilities only.

Starting in 1992 the energy flow diagrams shown in Figs. 1 and 2 reflect losses associated with electric conversions by the small independent power producers. Their collective sales of electricity to the utilities have been part of the public record and included in the charts; however heretofore the fuels or type of energy used to produce electricity have not been available in a timely manner. Hence it has not been possible to estimate conversion losses. Generally the small power producers utilize energy sources, such as biomass or geothermal, whose conversion efficiency to electricity is lower than the conventional fossil fuels used for power production. Efficiency of fossil-fueled electric utility boilers is approximately $33 \%$ whereas the average efficiency of all biomass plants operated by nonutilities is approximately $12 \%^{3}$ and $18 \%$ for geothermal plants.

Electricity consumed by the residential/commercial end use sectors shown in Figs. 1 and 2 include an "other" category of consumption tabulated by the U.S. Department of Energy. It includes street and highway lighting and other sales to public authorities as well as sales to public railroads and railways. Lacking a breakdown in the "other" category (27 x 1012 Btu's in 1993) it is not possible to indicate how much of this electricity properly belongs in the transportation sector.

\section{CALIFORNIA'S ENERGY FLOW IN 1993 COMPARED TO 1992}

\section{The economy}

For the second year California did not experience the same economic upturn of the nation as a whole. Most economic indicators pointed to a continued state recession (Table 1). Notable was a high average unemployment rate of $9.2 \%$ compared to a national average of $7.1 \%{ }^{4}$ At year-end 
unemployment had dropped to $8.7 \%$ suggesting some improvement in the situation. This indicator is considered to be the broadest, most currently available measure of regional economic activity. Since reaching a peak in mid-1990, California has lost an estimated 900,000 jobs making this period the longest and deepest downturn in employment since World War II..$^{5}$ The loss of jobs is attributed to contraction of the defense industry within the state (especially the aerospace industry) and to a lesser extent the "downsizing" of corporations driven by efforts to remain competitive by cutting overhead costs and staffs. The shrinking of the defense industry in the state is expected to continue with the closure of many more federal installations such as Norton Air Force Base in San Bernardino County, Moffett Field, The Presidio, and Mare Island Naval Shipyard near San Francisco, Fort Ord in Monterey County and Castle Air Force Base in Merced County.

\begin{tabular}{|c|c|}
\hline Indicator & Percent change from 1992 \\
\hline Unemployment & +1.1 \\
\hline Housing units authorized & -13.2 \\
\hline New auto registrations & +2.7 \\
\hline Total taxable sales & -0.1 \\
\hline Corporate profits before taxes & $+2.8 \mathrm{est}$ \\
\hline Personal income & +2.4 \\
\hline Consumer price index & +2.6 \\
\hline
\end{tabular}

Another indicator of economic activity, the number of new construction projects started during the year (Table 2), similarly points to a continued recession through 1993 in the state. Home prices throughout the state fell $3.7 \%$ in 1993 compared to a $1.9 \%$ gain nationwide. 6

Table 2. Construction authorized by permit $-1993^{4}$

(Value in Millions of Dollars)

\begin{tabular}{|c|c|c|c|}
\hline \multirow{2}{*}{ Year } & \multirow{2}{*}{ Residential } & \multicolumn{2}{|c|}{ Nonresidential } \\
\hline & & Commercial & Other* \\
\hline 1988 & 26,361 & 6,569 & 7,592 \\
\hline 1989 & 27,790 & 6,159 & 7,507 \\
\hline 1990 & 20,686 & 5,270 & 7,466 \\
\hline 1991 & 15,056 & 3,374 & 6,247 \\
\hline 1992 & 14,451 & 2,472 & 5,683 \\
\hline 1993 & 12,932 & 2,137 & 5,420 \\
\hline
\end{tabular}

*Other consists of all other categories including additions and alterations of $\$ 100,000$ or more. 
The CA Department of Finance reported that California's population grew by less than 500,000 or $1.5 \%$ to 32 million in $1993 .{ }^{7}$ As of January 1,1994 there was a net gain of only 65,000 people from migration during the previous twelve months, the lowest number since record keeping began in 1940-41. All other factors being equal, the population increase presages a modest increase in energy demand for the year.

\section{Energy Consumption}

Overall energy use in California fell in 1993. A breakdown of the major fuels consumed and the principal end-use sectors consuming those fuels is given in Table 3 for the last decade. Consumption in the principal end-use sectors (residential/commercial, industrial and transportation) either remained at 1992 levels or declined.

An unusually large decrease in fuel usage in 1993 was registered by the industrial sector and the related non-energy sectors (Table 3 ). What is called non-energy here is consumption to produce products such as petrochemicals, fertilizers, waxes, lubrication oils, asphalt, etc. These products are not burned to produce energy. In California asphalt production which serves the road and highway construction industry is the largest contributor to the total. The decline in industrial consumption reflects the on-going recessional atmosphere that prevailed in the state during the year. Use of oil products by the industrial sector was primarily affected, but use of natural gas and purchases of electricity from the utilities fell as well (Fig. 1). Although the amount of electric power produced and used in-house by the industrial community is not included in this total, the fossil fuels used to produce that power are included. The drop in the amount of natural gas used by the industrial sector, the fuel-of-choice of self generators, suggests that the amount of electricity generated by industries for their own use declined as did the amount of power purchased from the utilities (shown in Figs. 1 \& 2). This is verified by information provided by the U.S. Department of Energy discussed in a later section titled Nonutility Generation.

Use of transportation fuels was lower but close to 1992 levels due to offsetting trends more completely explored in the TRANSPORTATION FUELS section that follows. Residential/ commercial consumption for the year declined a few percent as did use of natural gas by that sector. It is likely that a diminished demand for space heating because of a mild winter in populous Southern California (Table 4) more than offset the modest increase in population during the year. Natural gas is the principal fuel used for residential and commercial heating in California; both fuel oils and electrical resistance heating are only important in isolated areas lacking access to pipeline gas. 
Table 3

Comparison of Annual Energy Use in California

(in $10^{12} \mathrm{Btu}$ )

$\begin{array}{lllllllllll}1983 & 1984 & 1985 & 1986 & 1987 & 1988 & 1989 & 1990 & 1991 & 1992 & 1993\end{array}$

$\begin{array}{lrrrrrrrrrrr}\text { Natural Gas } & 1769 & 1865 & 2034 & 1697 & 2091 & 1932 & 2087 & 2069 & 2089 & 2132 & 2096 \\ \text { Crude Oil (less exports) } & 3329 & 3477 & 3580 & 3601 & 3591 & 3899 & 4015 & 3884 & 3731 & 3731 & 3536 \\ \text { Utility electric sales } & 622 & 700 & 673 & 697 & 718 & 744 & 757 & 763 & 713 & 729 & 719 \\ \text { Residential/Commercial } & 1268 & 1176 & 1325 & 1224 & 1325 & 1350 & 1403 & 1474 & 1442 & 1394 & 1377 \\ \text { Industrial } & 1395 & 1493 & 1648 & 1456 & 1439 & 1557 & 1646 & 1560 & 1616 & 1711 & 1563 \\ \text { Non-energy } & 183 & 221 & 185 & 203 & 292 & 235 & 237 & 252 & 245 & 250 & 242 \\ \text { Transportation } & 2313 & 2464 & 2384 & 2499 & 2564 & 2715 & 2781 & 2817 & 2800 & 2707 & 2692 \\ & & & & & & & & & & & \\ \text { Total Energy Consumption } \dagger^{\dagger} & 5900 & 6200 & 6400 & 6200 & 6600 & 6750 & 6950 & 6900 & 6800 & 7200 & 7000 \\ & & & & & & & & & & \end{array}$


Table 4. Weather Comparison, 1968 - 1993

(Annual Heating Degree Days**)

\author{
San Francisco \\ Federal Office \\ Building
}

1968

1969

1970

1971

1972

1973

1974

1975

1976

1977

1978

1979

1980

1981

1982

1983

1984

1985

1986

1987

1988

1989

1990

1991

1992

1993

Normal

1951-80

1961-90***
2942

3066

3006

3468

3240

3161

3182

3313

2665

2888

2599

2545

2799

2819

3195

2386

2648*

2486*

$1842 *$

2150*

2194*

$2340^{*}$

$2422 *$

1718*

2071*

2750

3005
$2526^{*}$
Los Angeles

Civic Center

850

1032

941

1424

918

1066

1084

1548

1128

911

1208

1160

597

506

975

602

704

921

473

979

867

844

839

879

705

680

1204

1154
San Diego

Lindbergh

Field

1052

1145

1137

1657

1166

1137

1123

1416

793

747

736

902

590

573

913

623

713

1079

843

1201

1102

1068

1172

1212

866

948

1284

1256

* CA. Mission Dolores - same historical data as for Federal Office Building

** A "degree day" is a term that describes the relationship of energy consumption to outdoor temperatures. "Heating or cooling degree days" are deviations of the mean daily temperature from $65^{\circ} \mathrm{F}$. For example for a day with a mean temperature of $40^{\circ} \mathrm{F}$, the "heating degree days" would be 25 and the "cooling degree days" 0 . Annual heating degree days are the sum for the year. Greater number of heating degree days means greater fuel requirements.

*** Revised 1993.

Source: Local Climatological Data for San Francisco, Los Angeles and San Diego, National Oceanic and Atmospheric Admin., National Climatic Data, Asheville, NC. 
As noted earlier, for the first time we have included estimates of conversion losses of small power producers (biomass, geothermal, coal coke, small hydropower) in tallies of energy consumption and in energy flow diagrams (Figs. 1 and 2). This addition necessarily results in larger totals for energy consumption (Table 3 ) than otherwise would be reported and invalidates comparisons of total energy consumption in the years prior to 1992. It should be noted, however, that the contributions of the group were small until about 1985.

\section{TRANSPORTATION FUELS}

\section{Consumption}

Use of all transportation fuels decreased slightly in 1993 (Tables 3 and 5). Gasoline sales increased approximately $1 \%$ reflecting an increase in both the number of licensed drivers and the number of miles traveled on the state's highway system. ${ }^{8}$ The latter rose for the nineteenth consecutive year. ${ }^{8}$ Also impacting gasoline usage was the slight drop in the efficiency of the nation's passenger car fleet in both 1992 and 1993. In 1993 it was estimated to average 21.64 miles per gallon nationwide. 9

While sales of jet fuels grew with increased number of commercial air flights, sales of aviation gasoline fell for the fifth consecutive year. ${ }^{8}$ The slight decrease in sales of highway diesel fuels may reflect both the economic recession that prevailed in 1993, the boycott of some truckers who sought out-of-state supplies in preference to the new reformulated diesel oils that became standard output of California refineries at the end of the year (See Vehicle Emission Standard Section) or both factors. The sale of vessel bunkering fuels at California ports is continuing to be affected by new state taxes imposed in mid-1991.

Ridership on almost all types of public transit systems fell substantially in 1993. Intercity bus travel as reported by Greyhound Lines Inc. fell 45\%; annual bus transit as reported by eleven major operators was down $\sim 6 \%$; intercity and commuter rail ridership was spotty with the largest system, Bay Area Rapid Transit with 73.5 passengers in 1993, showing 0.3\% drop in the number of passengers. 8

\section{Vehicle Emission Standards}

On October 1, 1993 both the state and the federal reformulated diesel fuel regulations took effect. The California Air Resources Board (CARB) standards for diesel are similar but more stringent than the Environmental Protection Agency's. (The reformulated gasoline regulations are not scheduled for implementation until January 1,1995 .) The objectives are to reduce emissions of $\mathrm{SO}_{2}, \mathrm{NO}_{\mathrm{x}}$ and particulate matter under 10 microns in size; however at least three California refiners 
Table 5. California Transportation End Use

(in $10^{12} \mathrm{Btu}$ )

\begin{tabular}{lllllll}
1987 & 1988 & 1989 & 1990 & 1991 & 1992 & 1993 \\
\hline
\end{tabular}

\begin{tabular}{|c|c|c|c|c|c|c|c|}
\hline Net gasoline* & 1576 & 1612 & 1630 & 1664 & 1712 & 1670 & 1681 \\
\hline Net aviation fuel & 390 & 427 & 458 & 475 & 476 & 510 & 520 \\
\hline $\begin{array}{l}\text { Taxable diesel fuel } \\
\text {-public highways }\end{array}$ & 174 & 244 & 265 & 253 & 246 & 256 & 253 \\
\hline Rail diesel & 30 & 26 & 30 & 31 & 33 & 30 & 27 \\
\hline Net bunkering fuel & 347 & 357 & 348 & 344 & 288 & 202 & 193 \\
\hline Military & 28 & 29 & 30 & 29 & 26 & 23 & 7 \\
\hline $\begin{array}{l}\text { Natural gas-pipeline } \\
\text { fuel }\end{array}$ & 13 & 20 & 20 & 21 & 19 & 16 & 12 \\
\hline Natural gas vehicular & - & - & - & 0.004 & 0.01 & 0.03 & 0.27 \\
\hline Total** & 2565 & 2715 & 2781 & 2817 & 2800 & 2707 & 2693 \\
\hline
\end{tabular}

Source: Fuel and Kerosene Sales, DOE/EIA, 1993; Quarterly Oil Report, Fourth Quarter 93 (Net gasoline and aviation fuel), California Energy Commission, Sacramento, CA; Natural Gas Annual1993 DOE/EIA-0131(93) Table 52, Department of Energy, Washington, DC (October 1994).

(Exxon, Mobil and Shell) initially declined to produce a diesel that met CARB standards. A combination of added refining costs, shortages of reformulated diesel and a new federal highway tax of 4.3 cents per gallon also imposed on October 1 led to a large price increase in the price of diesel in the first few months of the program; the average weekly price of diesel fuel per gallon in California jumped 45 cents per gallon; however as the supply met demand the price declined. 10

Escalating prices were not the only consumer complaint. Within weeks of appearance of the reformulated fuel at truck stops, truckers began complaining of malfunctioning engines. Subsequently almost every class of diesel-burning vehicle was on record as having problem with fuel pumps and seals. ${ }^{11}$ Truckers that were able began refueling out-of-state. Governor Pete Wilson refused to suspend the regulations on appeal by the California Trucking Association, and within a few months numerous class action suits were filed by vehicle owners against the refiners (Chevron and ARCO), and legislation was introduced in both the California Assembly and Senate to either ban the state-mandated fuel, modify fuel standards or reimburse consumers whose fuel systems suffered damage. Almost a year to the day after the regulations went into effect Governor 
Pete Wilson signed into law a bill that provides remuneration to vehicle owners whose engines were damaged by the cleaner-burning diesel fuel. A Task Force appointed by the Governor concluded that the problem affected a relatively small percentage of the state's vehicles, and the regulations still stand. The two class action suits against the refiners are still pending. Ironically the money for the reimbursements will come from a special fund financed by penalties paid by oil refiners who did not meet a state-imposed deadline for producing the cleaner-burning fuel. 12

There was growing pressure during 1993 on the CARB to modify its 1990 ruling that $2 \%$ of all the new cars sold in the state in 1998 (about 40,000) be "zero emission" vehicles, presumably powered by electricity; the mandated share is to rise to $10 \%$ in 2003 . The oil industry and the auto industry are foremost opponents of the ruling, but nevertheless the latter industry has launched substantial programs designed to meet the requirement with battery-operated vehicles. The CARB has shown no inclination to back down, citing the extensive $R \& D$ on electric vehicles and notable advances in battery technologies that have taken place since the requirement became law. ${ }^{13}$ Critics argue that if the intent of CARB is to eliminate air pollution from some part of the state's highway vehicles, it is taking the wrong tack. They point out that unless the requisite electricity to charge the car batteries is derived from out-of-state sources, it will almost certainly be generated by burning fossil fuels within the state with attendant air pollution.

\section{OLL AND GAS PRODUCTION}

\section{Qil Production}

California's oil production continued its inevitable decline although it maintained its fourth place position in the nation as a whole behind Texas, Alaska and Louisiana with production of 343.7 million barrels in 1993. The largest declines were registered in onshore fields, particularly at the South Belridge field near Bakersfield where production was down 3.6 million barrels. Nonetheless it was the second largest producing field in the state. ${ }^{14} \mathrm{~A}$ bright spot in the onshore production picture was a substantial increase ( 1.2 million barrels) in output for the fifth consecutive year at the Lost Hills oil field, also in Kern County, as a consequence of doubling of enhanced oil recovery operations during the year. The field was discovered in 1910. However despite anticipated enlargement of so-called "incremental oil" or secondary oil production projects, decline in onshore production is expected to continue at $2.5-3.5 \%$ per year into the foreseeable future. ${ }^{15} \mathrm{It}$ currently accounts for $62 \%$ of total California oil production.

The decline in production for the state as a whole would have been greater except for a large increase in offshore production within the OCS (outer continental shelf) province under federal jurisdiction. Specifically production increased 8.9 million barrels at the Point Arguello field near Santa Barbara County and 0.8 million barrels at the Sockeye field near Ventura County. 
The giant Point Arguello field 10 miles offshore was expanded 35,000 barrels per day when permission to off-load crude oil to tankers from offshore platforms was obtained January 1, 1993 from the California Coastal Commission. ${ }^{16}$ The permit expires in three years at which time the owners are required to have built a direct pipeline to Los Angeles refineries. The permission followed many years of controversy concerning movement of the oil from offshore production platforms to shore. In order to start production, Chevron had been shipping Point Arguello oil to shore via an existing, small capacity underwater pipeline thence by pipeline to northern California where it was shipped by tanker to Los Angeles transiting the Santa Barbara coast en route. The Santa Barbara County officials thus realized little advantage from their long standing opposition to Point Arguello crude oil being transported directly to refineries in tankers. With expected additional production from new offshore platforms in the Santa Ynez Unit in the Santa Barbara Channel that will also need transportation to refineries, there has been active interest in construction of the proposed new line by several pipeline companies. ${ }^{17}$

\section{Natural Gas Production}

In 1984-1985 the volume of gas produced in association with oil production was similar to the amount produced in gas fields unassociated with oil production. In the interim both volumes have declined, but "nonassociated" gas has shown the largest decrease reflecting the steadily declining contributions from offshore fields. Natural gas produced in 1993 (317.6 Bcf) was less than half of that produced in the record setting year of 1968 (714.9 Bcf). ${ }^{14}$ Continued decline in California production is anticipated.

\section{OIL AND NATURAL GAS SUPPLY}

\section{Qil Supply}

The state has relied on California production to supply 50-55\% of demand for several decades. In 1973 the remainder was supplied principally by foreign sources with only $10 \%$ being supplied by other states. By contrast, in 1993 the largest source of out-of-state crude oil and refined products was the state of Alaska; foreign oil entering California refineries fell to about $5 \%$ of demand. The turning point was the opening of the Trans-Alaskan Pipeline from the super-giant Prudhoe Bay field on the North Slope of Alaska to Valdez on Prince William Sound in 1977. While that supply augmented by subsequently discovered and developed oil resources on the North Slope has been more than adequate to meet California's growing demand for oil, the Prudhoe Bay field in Alaska has started a slow decline in production which is expected to increase to $6 \%$ per year to the year 2000 and thereafter to $15 \%$ per year. ${ }^{15}$ By the turn of the century the projected cumulative decrease in the supply of both California and Alaskan crude oil promises to force 
California to turn to foreign sources for the bulk of its oil. The possibility of significant new discoveries on portions of the North Slope, Alaska that are currently accessible to drilling or that the Arctic Wildlife Refuge will be opened for exploration of its estimated more than 3 billion barrel resource are considered remote by most analysts.

\section{Natural Gas Supply}

Slightly less than two-thirds of the supply of natural gas in California derives from southwestern states, principally New Mexico and west Texas. Local state production provides $17 \%$ as also do imports from Canada. The supply to the State was more than adequate although the long lived "gas bubble," which is the difference between maximum feasible gas capacity and actual deliveries, was declined to about $4 \% .18$ There was a sharp increase in wellhead prices in 1993 (\$2.02/Mcf up sharply from $\$ 1.74 / \mathrm{Mcf}$ the previous year) driven by the demands of the very cold winter of 1993-1994 in the U.S.

Completed in 1993 was Pacific Gas Transmission Corp.'s 840-mile pipeline to deliver 903 million cf/day of Canadian gas to western markets. It provides 755 million cf/day of firm capacity to Northern and Southern California and 148 million cf/day to the Northwest states. ${ }^{19}$ This pipeline is one of four, new or expanded lines into the State that have been completed in the 19911993 period. Collectively they have increased pipeline capacity by about $50 \%$. Increase in demand for natural gas has come from all sectors; however the largest increase in demand has been driven by pollution laws that have impacted heavy oil producers who formerly burned raw crude oil and heavy refined oils to raise steam for steam flooding in California's heavy oil fields. Another growing group of large gas users are electric cogenerators and self generators who turn to gas for a variety of reasons, the most important of which are the low capital costs associated with use of gas turbines for electric generation and the clean-burning characteristics of the fuel which minimize use of pollution control devices.

In an effort to encourage the use of natural gas and to keep its price attractive, various federal and California agencies have encouraged competition within what has been a monopolistic industry. This was accomplished by separating purchase, storage and delivery services and allowing customers to purchase only those services they want. Thus heavy oil producers can independently contract for natural gas from out-of-state producers as well as for its transport into the state by pipelines which may or may not be owned by the utility that formerly served them. Loss of such large customers poses problems for the regulated utility industry and regulators alike since the utilities' fixed costs must be passed on to their remaining customers and in particular to the small ratepayers. The hope on the part of the regulatory agencies is that the utilities will compete for service to the bypassing industries by lowering their costs and hence prices and by 
offering other inducements such as reliability and security of supply in order to keep them as customers.

\section{ELECTRICAL POWER}

\section{Source of Supply}

Electricity distributed by California utilities derives from numerous sources - imports from out-of-state generators - principally from the southwest U.S., utility generators utilizing fossil fuels, hydropower, geothermal energy and nuclear reactors, and from purchases from nonutility generators using a variety of fuels (Table 6). Utility generating capacity by fuel source is given in Table 7.

Table 6. Sources of California Utilities' Distributed Electricity- 1993

Source

Imports

Out-of-state coal facilities Purchases

Fossil fuels

Natural gas

Oil

Nuclear power (in-state)

Hydropower

Geothermal power

Windpower

Cogeneration

Biomass, solar, \& coal

TOTAL
Net electrical energy (trillion Btu)

172

66

106

166

159

7

Table 7. California Utility Electrical Generating Capacity ${ }^{20}$

\begin{tabular}{|c|c|}
\hline $\begin{array}{c}\text { Primary energy } \\
\text { source }\end{array}$ & $\begin{array}{r}\text { Capacity } \\
\text { (GWe) }\end{array}$ \\
\hline Petroleum & 1.93 \\
\hline Gas & 22.91 \\
\hline Water & 13.45 \\
\hline Nuclear & 4.31 \\
\hline Other (principally geothermal) & 1.72 \\
\hline TOTAL & 43.77 \\
\hline
\end{tabular}

* Summer capability as of December 31, 1993 


\section{Nuclear Power}

The contribution from the state's two nuclear installations (San Onofre, San Diego Co. and Diablo Canyon, San Luis Obispo Co.) fell 10\% in 1993. Diablo Canyon, the subject of great safety concerns a decade ago, however, produced a record amount of power and the two $\sim 1000 \mathrm{MW}$ units operated at a combined $89 \%$ capacity $^{21}$ compared to an industry average of 70.5\%. ${ }^{22}$ Commercial operation started in 1985-1986.

The rate settlement with the California Public Utilities Commission effective mid-1988 ties the return on investment in the Diablo Canyon nuclear plant to the amount of electricity generated rather than to the traditional cost-based rate determinations. In 1993 the return to Pacific Gas and Electric Co., the owner, was 11.6 cents per kwh - up from 7.8 cents per kwh in 1988 reflecting increased output over the period. This has been accomplished by a variety of efficiency measures, the most efficacious being the reduction in refueling time from 129 and 82 days for the two units, respectively, in 1988 to 59 and 57 days for the two in 1993. Ninety two days is average for comparable plants. As each unit produces about $\$ 3$ million of revenues per day at full operating power, shortening of the refueling time has increased PG\&E's revenues substantially. ${ }^{19}$ The plant has been on the Nuclear Regulatory Commission's list of best plants for five consecutive years.

\section{Hydropower}

Noteworthy in 1993 was the doubling of the contribution of hydropower (Compare Figs. 1 and 2). The 1992-1993 winter rains restored state reservoirs to near capacity levels representing a respite from the drought that had prevailed in the previous years.

\section{Nonutility Generation}

Also noteworthy was the large contribution to supply made by nonutility generators. Collectively California's independent generators produce more electricity than any comparable group in the U.S. ${ }^{23}$ Texas also produces significant amounts of nonutility generated electricity; however in contrast to California (Table 8), two-thirds of it is used by the independent power producers themselves and does not find its way into the Texas grid.

Table 8.23 Production of electricity by California utilities and nonutilities (Billion kwh)

Net generation by public utilities Gross* generation by nonutilities Receipts (purchases, exchanges, etc.)

Deliveries to utilities

Facility Use

\begin{tabular}{rr}
1992 & Year \\
\hline 119.3 & 1993 \\
67.0 & 125.8 \\
4.4 & 62.8 \\
50.5 & 3.0 \\
13.1 & 53.4 \\
& 12.4
\end{tabular}

* Note: The gross-to-net generation conversion factor varies from 0.99 to 0.97 depending on the type of prime mover. 23 
More than half of California nonutility generators are cogenerators. ${ }^{24}$ The fuel of choice of the cogenerators is overwhelmingly natural gas. The remainder are small power producers who utilize hydropower, wind, biomass, coal coke, solar or geothermal energy to operate qualified facilities that meet certain ownership, operating and efficiency criteria established by the Federal Energy Regulatory Commission pursuant to the Public Utility Regulatory Policies Act of 1978 (PURPA). Geothermal operators are the largest contributor to power production amongst the small power producers. The next largest contributors use biomass residues from lumber operations and food processing (peach pits, husks,etc.) or methane from manure or land fills. ${ }^{25}$ In Figs. 1 and 2, utility and nonutility production have been combined in the case of geothermal, wind, solar, and hydropower.

The Public Utility Regulatory Policies Act, which encouraged independent power production by requiring the public utilities to purchase nonutility generated electricity, and the Energy Policy Act of 1992, which required the public utilities to transmit electricity generated by the independent power producers, set the stage for radical restructuring of the electrical power industry in the United States. These Acts potentially give independent power producers access to big and small retail customers and give customers the opportunity to chose their supplier. It is not surprising in view of the large size of the nonutility generating industry within the state that within months after the passage of the Energy Policy Act, the California Public Utilities Commission's (CPUC) Division of Strategic Planning began examining the future of electric industry regulation. Its focus was the likely new competition between the theretofore monopolistic public utilities and the independent power generators. By the end of 1993 the CPUC had almost finished formulating a proposal to allow out-of-state utilities to sell power directly to large industrial and commercial users starting in 1996 and to residential users six years later. The intent was to unveil a formal proposal in 1994 for public comment. The objective of the CPUC proposal is to prod the public utilities to improve their efficiencies and cut their costs in order to meet the competition. The CPUC must grapple with the prospect of the likely early loss of some of the utilities' large customers associated with relatively high profit margins and with the specter of compensating increases in the rates of the small users with large service requirements. Irrespective of the exact details of the proposal, one ramification of such change is that utility stocks and bonds, long regarded as stable investments, would become more risky and volatile on the stock and bond market.

\section{Alternate Sources of Electricity}

Geothermal

Collective output from the state's geothermal fields was slightly up in 1993 (Table 9) despite continuing decline in steam production (and thus generated electricity) at The Geysers in 
Table 9. Principal Geothermal installations in California (1993) ${ }^{14}$

\begin{tabular}{|c|c|c|c|c|c|c|}
\hline \multirow[t]{2}{*}{ Field } & \multicolumn{3}{|c|}{$\begin{array}{l}\text { Gross installed } \\
\text { capacity (MWe) }\end{array}$} & \multicolumn{3}{|c|}{$\begin{array}{l}\text { Steam/fluid production } \\
\text { (billions of kilograms) }\end{array}$} \\
\hline & 1991 & 1992 & 1993 & 1991 & 1992 & 1993 \\
\hline Coso Hot Springs & 260 & 260 & 260 & 46.6 & 41.2 & 47.7 \\
\hline East Mesa & 130 & 130 & 125 & 91.9 & 97.6 & 97.6 \\
\hline The Geysers & 1900 & 1900 & 1900 & 89.7 & 88.5 & 84.4 \\
\hline Heber & 52 & 52 & 85 & 29.2 & 29.5 & 39.7 (est.) \\
\hline Mono-Long Valley & 40 & 40 & 40 & 24.5 & 24.6 & 23.5 \\
\hline Salton Sea & 240 & 240 & 240 & 77.7 & 78.0 & 78.0 \\
\hline Wendell-Amedee & 3 & 3 & 3 & 8.2 & 8.5 & 7.9 \\
\hline Total & 2625 & 2625 & 2663 & & & \\
\hline
\end{tabular}

Sonoma County, the world's largest geothermal field. Its generating plants are owned and operated principally by northern California utilities. Six geothermal wells associated with the partially completed South Geysers Power Plant were plugged and abandoned. The project was canceled because of insufficient steam at the site. The decline at The Geysers was more than offset by startup of a new 33-megawatt (net) binary power plant at Heber Geothermal field near the Mexican border. Eleven production wells producing $167^{\circ} \mathrm{C}$ brine and 14 injection wells returning $71^{\circ} \mathrm{C}$ fluid to the reservoir service the plant. 14

\section{Solar Electricity}

The use of solar-heated hot water is unmonitored in the state; hence the size of solar energy's contribution to the state's slate of utilized energy resources is unknown, but it is probably substantial.

Most solar electric projects are experimental in nature or demonstrations. Three small commercial units in Yolo, San Luis Obispo and Fresno Counties are operated by the consortium called Photovoltaics for Utility Scale Applications (PVUSA) made up of the U.S. Department of Energy, the California Energy Commission, the Electric Power Research Institute and seven utilities. The three plants have a combined nominal capacity of $2 \mathrm{MW}$. A plant located at Davis, CA was purchased from Advanced Photovoltaics Systems Inc. in 1993 by PVUSA. ${ }^{26}$ It utilizes 9,600 thin film, amorphous silicon modules. The Sacramento Municipal Utilities District operates two 
additional photoelectric plants with 2 MW capacity in Solano and Sacramento Counties. The output of all of these solar electric plants is put into the utility electric grid; however it is small approximately 2.7 million kwh.

\section{Windpower}

The number of wind turbines operated by nonutilities in the state during 1993 decreased by $3.5 \%$ primarily due to changes in the Altamont Pass installations (Table 10). Capacity factors at the Altamont likewise fell from $17 \%$ to $14 \%$; however an increase of $4 \%$ in capacity factors at windfarms in the Tehachapi Mountains, the second largest installation in the state, more than compensated so that the state wide average rose slightly. The total amount of electricity generated by the collective farms in 1993 was 3.418 billion kwh. ${ }^{24}$

Table 10. Windpower installations in California as of January $\mathbf{1}^{24}$

Location

Altamont Pass area 45 miles east of San Francisco

San Gorgonio Pass, Riverside Co. near Palm Springs

Tehachapi Pass, Kern Co.

Carquinez Strait, Solano Co.

Pacheco Pass, San Benito Co.

TOTAL

Capacity Factor*

\begin{tabular}{rrrrrrrrr} 
& \multicolumn{1}{c}{ Capacity } & $\left(M W_{e}\right)$ & \multicolumn{6}{c}{ Number of turbines } \\
1991 & $\underline{1992}$ & $\underline{1993}$ & $\underline{1994}$ & $\underline{1991}$ & $\underline{1992}$ & $\underline{1993}$ & $\underline{1994}$ \\
687 & 704 & 683 & 638 & 6524 & 6818 & 6451 & 5952 \\
& & & & & & & \\
229 & 255 & 263 & 267 & 3333 & 3581 & 3646 & 3683 \\
& & & & $\cdot$ & & & \\
477 & 644 & 632 & 627 & 4422 & 5221 & 4992 & 4908 \\
& 60 & 60 & 60 & & 600 & 600 & 600 \\
61 & 16 & 16 & 16 & 631 & 167 & 167 & 167 \\
& & & &. & & & \\
1454 & 1679 & 1655 & 1608 & 14910 & 16387 & 15856 & 15310 \\
20 & 20 & 19 & 20 & & & &
\end{tabular}

*Capacity factor is defined as the ratio of actual energy output to the amount of energy a project would produce if it operated at full rated power for 24 hours per day within a given time period.

The California wind industry remains sanguine. There has been new foreign interest in the technology being developed in the U.S. Led by U.S. Windpower Inc., a Kenetech subsidiary, it has continued to improve efficiencies by replacing older machines with more sophisticated models. For example, the new generating turbines spin at variable speeds depending on wind velocity, and a computerized converter produces a steady 60 -hertz current formerly only possible with constant velocity turbines. Thus the amount of energy captured is not limited by the cut-in and cut-out velocities associated with earlier models. The cost to generate a kilowatt of electricity has fallen 
with the improved turbines to a reputed 5 cents. ${ }^{27}$ Nonetheless the average for the industry is several cents higher.

Most installations are "qualified facilities" using renewable resources under PURPA and thus eligible for favorable purchase agreements based on "avoided costs" of the utility purchasing the power. The "avoided cost," which is based on fuel and maintenance costs only, has declined substantially in the last decade and with it the cost of power purchases from "qualified facilities." In northern California new "qualified facilities" signing contracts with the utilities received 3-4 cents per kwh in 1993 depending on seasonal factors and time-of-day availability of the power. There is an added 1.5 cents per kwh in the form of a tax credit authorized by the Energy Policy Act of 1992 which improves profitability of new facilities. Many of the old contracts with the utilities pay as much as 10 cents/kwh. According to a Pacific Gas and Electric spokesman, about one-third of their purchases from "qualified facilities" including those from wind generators are associated with older, higher priced ( 10 cents/kwh) contracts. ${ }^{28}$ The latter typically run 10 years, and it was his opinion that most would expire within the next six years. 


\section{APPENDIX A}

Energy balance for 1993 (Fig. 1)

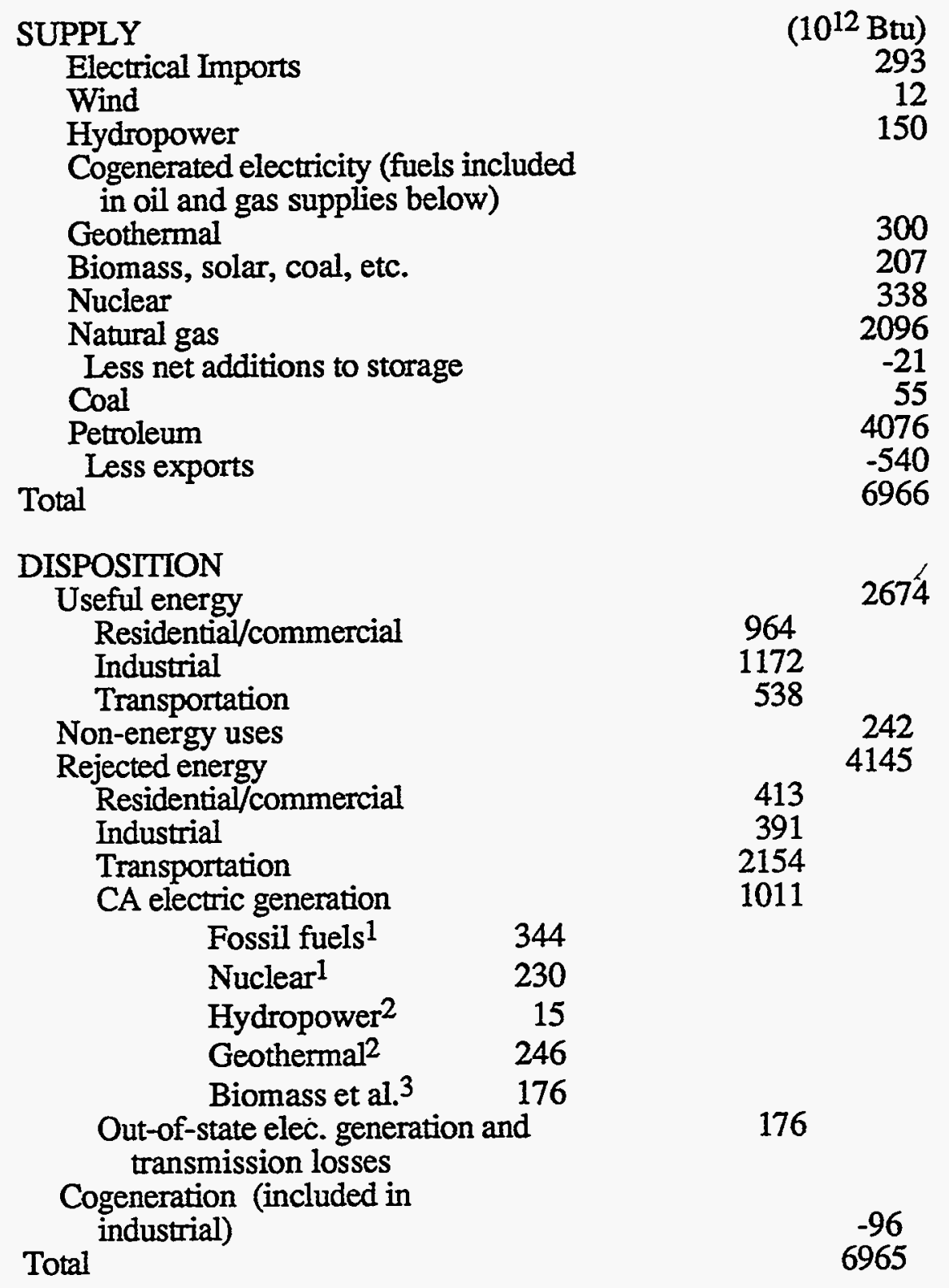

1) Utility generation

2) Combined utility \& nonutility generation

3) Nonutility generation only 


\section{APPENDIX B}

Data Sources for California Energy Supply (1993)

\section{Production}

Crude Oil including Federal

Offshore and Lease Condensate

Associated and Non associated

Natural Gas (marketed, dry)

Electric Utility Fuel Data

Electrical Generation

Utility -oil, gas, hydro, nuclear,

Wind

Cogeneration \& various small, nonutility power producers

Imports

Natural Gas

Foreign

Domestic

Crude Oil

Foreign and Domestic

Oil Products

Foreign and Domestic

Coal

Electrical Power

Net Exchange

Coal

\section{Exports}

Oil Products

Foreign and Domestic

(not including bunkering fuel

supplied at Califomia ports)
Source

Ref. 14.

Ref. 29, Table 52, Summary Statistics for Natural Gas - California.

Ref. 23, Table 18, Consumption of Petroleum \& Natural Gas to Produce Electricity.

Ref. 23, Table 13,

Net Generation from Electric Utilities by energy source.

Andrea Gough, California Energy

Commission, January 23, 1995.

Andrea Gough, California Energy

Commission, personal communication, January 23, 1995 \& January 25, 1995.

Ref. 29, Table 9.

Ref. 29, Table 52.

Ref. 30, Table 1-A, California

Petroleum Summary.

Ref. 30, Table A-1, California Fuels Market Petroleum Activity.

Ref. 31, Table 46, Coal Consumption by Census Division and State.

Andrea Gough, California Energy

Commission, personal communication, January 17, 1995.

Ibid.

Ref. 30, Table A-1. 


\section{APPENDIX $\mathbb{C}$}

Data Sources for California End Uses (1993)

Net Storage

Natural Gas

Unaccounted for Natural Gas

Transportation

Crude Oil

Gasoline, Aviation and Jet fuels

Taxable Diesel Fuel

(for public highways)

Vessel Bunkering

(includes international bunkering)

Rail Diesel

Military Use

Natural Gas

Pipeline fuel

Industrial, Government, Agriculture, etc.

Natural Gas

(includes lease and plant fuel)

Coal

Electricity

Crude Oil

Non Energy Applications

Crude Oil and LPG

Asphalt

Petrochemical Feedstock

Waxes, Lubricating oils, Medicinal uses, Cleaning

Residential and Small Commercial

Natural Gas

Crude Oil and Other Oils

(kerosene, residual, and distillate)

LPG

Miscellaneous “Off highway” Diesel

Electricity
Ref. 29, Table 52

Ref. 29, Table 52

Ref. 30 Table 1-A

Ref. 32, Table 4, Sales for Transportation

Use: Distillate Fuel Oil End Use, 1993

Ref. 32, Table $4 \& 5$

Ref. 32. Table 4

Ibid

Ref. 29, Table 52

Ref. 29, Table 52

Ref. 31, Table 46

Ref. 23, Table 26 Sales of

Electricity to Ultimate Consumers by

Class of Service, Year to date

By Difference

Ref. 33

Ref. 34, Table 42 (estimate) \& Ref.35

Table 12

Quarterly Oil Reports 1994

Ref. 29, Table 52

Ref. 32, Table 6, Sales of Kerosene by End Use; Table 5, Sales of Residual Fuel Oil by End Use; Table 4, Sales of Distillate Fuel Oil by End Use.

Ref. 34, Tables $43 \& 44 \&$ Ref. 35, Table 12

Ref. 32, Table 4

Ref. 23, Table 26 


\section{APPENDIX D}

\section{Conversion Units}

Energy Source

Electricity

Coal

Natural Gas

Crude Oil

Fuel Oil

Residual

Distillate, including diesel

Gasoline and Aviation Gasoline

Kerosene and Kerosene-type jet fuel

Asphalt

Road Oil

Synthetic Rubber and Miscellaneous

LPG Products
Conversion factor, $10^{6} \mathrm{Btu}$

3.415 per million $\mathrm{Wh}$

22.6 per short ton

1.05 per Mcf

5.80 per barrel

6.287 per barrel

5.825 per barrel

5.253 per barrel

5.67 per barrel

6.636 per barrel

6.636 per barrel

4.01 per barrel

Assumed Conversion Efficiencies of Primary Energy Supply

Electric Power Generation

Hydropower

Coal

Geothermal

Oil and Gas

Uranium

Biomass

Transportation Use

Residential/Commercial Use

$70 \%$

Industrial Use

$75 \%$ 


\section{REFERENCES}

1. a. E. Behrin and R. Cooper, California Energy Outlook, Lawrence Livermore Laboratory Report, UCRL-51966, Rev. 1 (1976).

b. I. Y. Borg, California Energy Flow in 1976, 1977 Lawrence Livermore Laboratory Report, UCRL-52451 (1978) and UCID-18221 (1979), respectively.

c. A. L. Austin and S. D. Winter, U.S. Energy Flow Charts for 1950, 1970, 1980, 1985 and 1990. Lawrence Livermore Laboratory Report, UCRL-51487 (1973).

d. I. Y. Borg and C. K. Briggs, California Energy Flow in 1978, 1979, 1980, 1981, 1982 , $1983,1985,1986,1987,1988,1989,1990,1991,1992$ Lawrence Livermore Laboratory Reports, UCID-18760 (1980), UCID-18991 (1981), 18991-80 (1982), 18991-81 (1983), 1899182 (1983), 18991-83 (1984), 18991-85 (1986), 18991-86 (1987), 18991-87 (1989), 18991-88 (1989), 18991-89 (1991), 18991-90(1992), 18991-91(1993), 18991-92(1994), respectively.

e. I. Y. Borg and C. K. Briggs, "California's Energy Supply and Demand in 1984," Annual Review of Energy 11. p. 209-28 (1986).

2. I. Y. Borg and C. K. Briggs, U.S. Energy Flow -1993 Lawrence Livermore Laboratory Report, UCRL-ID 19227-93 (October 1994).

3. Electric Power Annual - 1993, U.S. Department of Energy, Washington, D. C., EIA/DOE-0348(93) p.8 (December 1994).

4. California Statistical Abstract-1994, California Department of Finance, Sacramento, CA, Tables I-3 and I-4 (December 1994).

5. California Economic Indicators, California Department of Finance, Sacramento, CA, p. 9 (January-February 1993).

6. K. Howe, "Home prices slid 3.7\% in California last year," San Francisco Chronicle p. D1 (February 3, 1994).

7. R. G. McLeod, "Economy blamed for drop in California's population growth rate," San Francisco Chronicle p. A22 (May 18, 1994).

8. Travel and Related Factors in California -Annual Summary 1993, California Department of Transportation, Sacramento, CA (1994).

9. Monthly Energy Review, DOE/EIA-0035(94/12) Table 1.10 (December 1994).

10. J. Pelline, "Truckers fume over State's new diesel fuel," San Francisco Chronicle p. C1 (December 24, 1993).

11. Editorial: "The diesel disgrace," San Francisco Chronicle (January 16, 1994). 
12. J. Pelline, "Drivers to be paid for diesel damage," San Francisco Chronicle, p. Di (September 29, 1994).

13. R. B. Gunnison, "Electric car promise could be unplugged," San Francisco Chronicle p. 1 (May 12, 1994).

14. 1993 Annual Report of the State Oil \& Gas Supervisor, California Department of Conservation, Sacramento, CA,. Publ. No. PRO6 (1994).

15. Fuels. California Energy Commission, Sacramento, CA, P300-93-019, p. 10 (February 1994).

16. "Direct tankering of Arguello oil begins," Oil and Gas J., p.38 (August 2, 1993).

17. "Pipelines scrambling to transport added crude from California OCS," Oil \& Gas J. p. 32 (Sept 6, 1993).

18. "Gas bubble appears to be shrinking: NGSA," Highlights Institute of Gas Technology 23, p. 2 (July 26, 1993).

19. Overview, Pacific Gas and Electric Co., San Francisco, CA, 61 pp (Spring 1994).

20. Inventory of Power Plants in the United States 1993, U.S. Department of Energy, Washington, DC, DOE/EIA-0095(93) (December 1994).

21. 1993 Financial and Statistical Report, Pacific Gas and Electric Co., San Francisco, CA (1994).

22. Monthly Energy Review, U.S Department of Energy, Washington, DC DOE/EIA0035(94/12), Table 8.1 (December 1994).

23. Electric Power Annual - 1993, DOE/EIA-0348(93), Tables 12 and 82, U.S. Department of Energy, Washington, DC (December 1994).

24. Andrea Gough, California Energy Commission, Sacramento CA, personal communication (January 17, 23, 25, 1995).

25. Calvin Wire, California Energy Commission, Sacramento, CA, personal communication (January 27, 1995).

26. D. Kaplan, "Utility Industry;s Photovoltaic Demonstration Moves Forward," The Energy Daily p. 3 (January 12, 1993).

27. "The sun shines brighter on alternative energy," Business Week, p. 27 (November 8, 1993).

28. John Tattas, Pacific Gas and Electric Co., San Francisco, CA, personal Communication (August 18, 1994).

29. Natural Gas Annual-1993, U.S. Department of Energy, Washington, DC, DOE/EIA-031(93) (October 1994). 
30. Quarterly Oil Report, 4th Quarter 1993, California Energy Commission, Sacramento, CA (April 1994).

31. Quarterly Coal Report, 4th Quarter 1993, U.S. Department of Energy, Washington, DC, DOE/EIA-0121(93) (May 1994).

32. Fuel Oil and Kerosene Sales 1993, U.S. Department of Energy, Washington, DC, DOE/EIA-0535(93) (September 1994).

33. Asphalt Usage 1993, United States and Canada Asphalt Institute, Lexington KY (May 1994).

34. State Energy Data Report-Consumption Estimates (1992), U.S. Department of Energy, Washington, DC, DOE/EIA-0214(92) (May 1994).

35. Petroleum Supply Annual- 1993 , Vol 1, U.S. Department of Energy, Washington, DC, DOE/EIA-0340(93/1) (June 1994). 